\title{
Evaluation of anthropogenic emissions of carbon monoxide in East Asia derived from the observations of atmospheric radon-222 over the western North Pacific
}

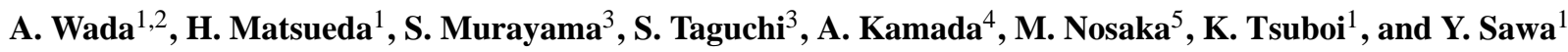 \\ ${ }^{1}$ Meteorological Research Institute, Tsukuba, Japan \\ ${ }^{2}$ Meteorological College, Kashiwa, Japan \\ ${ }^{3}$ National Institute of Advanced Industrial Science and Technology (AIST), Tsukuba, Japan \\ ${ }^{4}$ Osaka District Meteorological Observatory, Osaka, Japan \\ ${ }^{5}$ Saga Local Meteorological Observatory, Saga, Japan
}

Correspondence to: A. Wada (a-wada@met.kishou.go.jp)

Received: 22 May 2012 - Published in Atmos. Chem. Phys. Discuss.: 15 June 2012

Revised: 21 September 2012 - Accepted: 9 December 2012 - Published: 21 December 2012

\begin{abstract}
We used the observed $\mathrm{CO} / 222 \mathrm{Rn}$ ratio in the Asian outflows at Minamitorishima (MNM), Yonagunijima (YON), and Ryori (RYO) in the western North Pacific from 2007 to 2011, together with a three-dimensional chemical transport model (STAG), in order to estimate anthropogenic emissions of $\mathrm{CO}$ in East Asia. The measurements captured highfrequency synoptic variations of enhanced ${ }^{222} \mathrm{Rn}$ (ERN) events associated with the long-range transport of continental air masses. ${ }^{222} \mathrm{Rn}$ and $\mathrm{CO}$ showed high correlation during the ERN events observed at MNM and YON in the winter and spring, but not at RYO. The STAG transport model reproduced well the concentrations of observed ${ }^{222} \mathrm{Rn}$ when forced with a constant and uniform flux density of 1.0 atom $\mathrm{cm}^{-2} \mathrm{~s}^{-1}$, but underestimated the associated enhancement of synoptically variable $\mathrm{CO}$ caused by the underestimated flux values in the EDGAR ver. 4.1 emission database used in the model for East Asia. Better estimates for the East Asian emission were derived using a radon tracer method based on the difference in the enhancement ratio of $\mathrm{CO} / 222 \mathrm{Rn}$ between the observation and the model. The anthropogenic emissions of CO for China, Japan, and Korea were estimated to be $203 \mathrm{Tg} \mathrm{CO} \mathrm{yr}^{-1}, 91 \%$ of which originated in China. When compared with other estimated emissions of $\mathrm{CO}$, our estimated result showed consistency with those of the inverse method, whereas the emission database of EDGAR was about $45 \%$ smaller than our anthropogenic estimation for China.
\end{abstract}

\section{Introduction}

Recently, East Asia has become one of the large source regions of anthropogenic pollutants, along with North America and Europe. The emissions from East Asia continue to increase due to the growing economy and population (Akimoto, 2003). The continental outflow of pollutants from East Asia has had a significant impact on the environment in the downwind regions of the western North Pacific (Tanimoto et al., 2005). Several studies have also provided evidence of various influences on the air quality over certain regions of North America due to the long-range transport of polluted air masses from Asia (e.g. Andreae et al., 1988; Parrish et al., 1992; Husar et al., 2001).

The anthropogenic emission of trace gases from East Asia is not well quantified. In particular, emission estimates of carbon monoxide from incomplete combustion are characterized by large uncertainties due to the variability in the burning of fossil fuel, biofuel, and biomass in space and time. Bottom-up estimates based on the socioeconomic data have produced several emission databases, such as those of Streets et al. (2003), the Intercontinental Chemical Transport Experiment-Phase B (INTEX-B) emission inventory (Zhang et al., 2009), the Regional Emission inventory in Asia (REAS) (Ohara et al., 2007), and the Emission Database for Global Atmospheric Research (EDGAR) (Olivier et al., 2005). Another method to estimate surface emissions is to use a top-down approach, such as an inverse method (Heald

Published by Copernicus Publications on behalf of the European Geosciences Union. 
et al., 2004; Kopacz et al., 2009; Hooghiemstra et al., 2011). However, there are significant disagreements between the bottom-up and top-down emission estimates for East Asia (Heald et al., 2004; Palmer et al., 2006). Those disagreements are caused by substantial uncertainties associated with the insufficient knowledge about the source regions and the emission factors used to convert the socioeconomic data into emission values in the bottom-up approach, and by uncertainties in the atmospheric transport mechanism and the lack of sufficient observational data to constrain the model in the inverse method. In this study we propose a third, and independent, method to assess and evaluate the disagreement.

The radon tracer method has been used to estimate continental emissions of methane $\left(\mathrm{CH}_{4}\right)$ (Thom et al., 1993; Schmidt et al., 1996; Levin et al., 1999), nitrous oxide $\left(\mathrm{N}_{2} \mathrm{O}\right)$ (Schmidt et al., 2001), carbon dioxide $\left(\mathrm{CO}_{2}\right)$ (Schmidt et al., 2003; Hirsch, 2007), and chlorofluorocarbons (CFCs) (Biraud et al., 2000, 2002) in Europe. Radon-222 $\left({ }^{222} \mathrm{Rn}\right)$ has been used to parameterize transport and dilution of ground level emissions of trace gases in the atmospheric surface layer (Kuhlmann et al., 1998; Schmidt et al., 2001, 2003). ${ }^{222} \mathrm{Rn}$ is a radioactive noble gas with a half life of 3.824 days (e-folding time $\tau=5.52$ days) and is produced by the decay of radium-226 distributed uniformly in the soil. ${ }^{222} \mathrm{Rn}$ exhalation from soils has been found to be rather homogeneous in a restricted region and almost constant with time (Dörr and Münnich, 1990). The exhalation rate from the ocean is about two orders of magnitude less than that from soils (Wilkening, 1975). Thus, ${ }^{222} \mathrm{Rn}$ is a useful tracer for air masses originating from the land. Our study is the first to utilize the radon tracer method to obtain emission estimates of trace gases for East Asia.

The National Institute of Advanced Industrial Science and Technology (AIST) and the Meteorological Research Institute (MRI) have developed a high precision ${ }^{222} \mathrm{Rn}$ measuring system (Wada et al., 2010) and used it to measure atmospheric concentration of ${ }^{222} \mathrm{Rn}$ on the ground for more than three years at remote sites in the western North Pacific. In addition, the Japan Meteorological Agency (JMA) has been simultaneously measuring atmospheric concentrations of trace gases such as carbon monoxide (CO), carbon dioxide $\left(\mathrm{CO}_{2}\right)$, methane $\left(\mathrm{CH}_{4}\right)$, and ozone $\left(\mathrm{O}_{3}\right)$ at the same sites for more than a decade (Tsutsumi et al., 2006; Wada et al., 2007, 2011). Wada et al. (2011) showed that the combustion-related enhancement ratio of $\mathrm{CO}$ to $\mathrm{CO}_{2}$ observed at these sites depended on the emission ratio of $\mathrm{CO}$ to $\mathrm{CO}_{2}$ in East Asia. In addition, Wada et al. (2010) demonstrated that the enhanced ${ }^{222} \mathrm{Rn}$ peaks observed at MNM showed a high correlation with synoptic scale variation of $\mathrm{CO}$ observed simultaneously at this station. These results indicated that the emission ratios of the trace gases emitted from East Asia are conserved in the enhancement ratios reflected at these sites. Thus, emissions of the trace gases in East Asia can be estimated from the observed data over the western North Pacific by the enhancement ratio of $\mathrm{CO}$ and ${ }^{222} \mathrm{Rn}$.

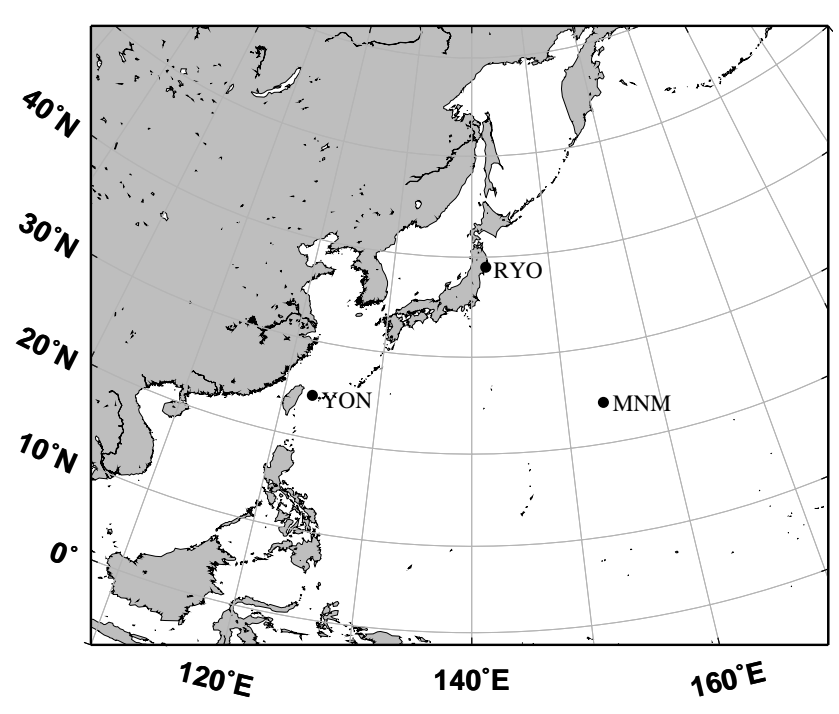

Fig. 1. Geographical locations of Minamitorishima (MNM), Yonagunijima (YON), and Ryori (RYO).

In this study, we show observational results of atmospheric ${ }^{222} \mathrm{Rn}$ and $\mathrm{CO}$ at the remote sites in the western North Pacific and resolve the relationship between ${ }^{222} \mathrm{Rn}$ and CO. Next, an estimation technique based on the radon tracer method is developed to obtain East Asian CO emission estimates based on the observed atmospheric ${ }^{222} \mathrm{Rn}$. Finally, we compare our estimated results with other estimated values by the bottomup and top-down methods.

\section{Sampling and analytical methods}

\subsection{Sampling sites}

The JMA is operating atmospheric monitoring stations at Minamitorishima $\left(24.3^{\circ} \mathrm{N}, 154.0^{\circ} \mathrm{E}, 8 \mathrm{~m}\right.$ above sea level), Yonagunijima $\left(24.5^{\circ} \mathrm{N}, 123.0^{\circ} \mathrm{E}, 30 \mathrm{~m}\right.$ above sea level), and Ryori $\left(39.0^{\circ} \mathrm{N}, 141.8^{\circ} \mathrm{E}, 260 \mathrm{~m}\right.$ above sea level) under the Global Atmosphere Watch programme of the World Meteorological Organization (WMO/GAW) (Fig. 1).

Minamitorishima (MNM) is a remote coral island in the western North Pacific, about $2000 \mathrm{~km}$ southeast of Tokyo. At this site, easterly winds associated with the maritime air masses prevail much of the year, except in the winter season, when the continental air masses from East Asia are transported by the synoptic scale weather systems. Since this island is very small, about $1.4 \mathrm{~km}^{2}$ with a population of about fifty people, the influence of local sources and sinks on the trace gas measurement is negligible as reported by previous trajectory analysis (Wada et al., 2007, 2011).

Yonagunijima (YON) is a remote island located about $111 \mathrm{~km}$ east of Taiwan. At this site, northeasterly winds associated with the continental high pressure system prevail, except in the summer when southerly wind associated with 
the maritime air masses dominates the site. Although the island is located at the same latitude as MNM, YON is situated immediately downwind of the Asian continent (Fig. 1), thus frequently influenced by the polluted air masses from Asia (Tsutsumi et al., 2006). Since the island is small, lightly populated and has little traffic, the local influence on the measurements is not significant as reported by the trajectory analysis (Wada et al., 2011).

Ryori (RYO) is located on the east coast of the northeastern part of Japan. Northwesterly winds from the Siberian high pressure system dominate the site throughout the year. In the summer season, however, southerly winds associated with the Pacific subtropical high pressure system are often observed. The station is located on the ridge of a hill along the sawtooth coastline facing the Pacific Ocean, at an elevation of $260 \mathrm{~m}$ above the sea level. Due to its geographical location and complex terrain around the station, RYO is influenced by local sinks and sources, along with air pollutants associated with the long-range transport of maritime and continental air masses.

\subsection{Measuring method}

The ${ }^{222} \mathrm{Rn}$ analyzer used in this study was developed by AIST and MRI (Wada et al., 2010) for precise measurements of atmospheric ${ }^{222} \mathrm{Rn}$. It is based on the electrostatic collection method that collects positively charged progenies of ${ }^{222} \mathrm{Rn}$ in the sampling air on the light sensitive photodiode (PIN photodiode) for an alpha particle detector charged high negative voltage. It automatically allows continuous measurement, to obtain hourly mean data from the data obtained every 10 minutes. Calibration of this analyzer was made at Nagoya University, with a detailed description of the calibration method given elsewhere (Iida et al., 1991, 1996). The detection limit of this measuring system is $0.16 \mathrm{~Bq} \mathrm{~m}^{-3}$ for hourly mean data.

The measurement by this ${ }^{222} \mathrm{Rn}$ analyzer has been made at MNM since September 2007, and at YON since November 2008. Our current sampling method is a commonly used one for greenhouse gas observation, and is described in Wada et al. $(2007,2010)$. Air is sampled at the top of a $10 \mathrm{~m}$ observational tower. After drying by the electric cooling units and membrane tube dryers, the sample air is introduced into the ${ }^{222} \mathrm{Rn}$ analyzer at a flow rate of $3.0 \mathrm{~L} \mathrm{~min}^{-1}$ at all the sites. The measurement of ${ }^{222} \mathrm{Rn}$ at RYO was started in March 2009 by using a commercially available ${ }^{222} \mathrm{Rn}$ monitor with a detection limit of about $0.5 \mathrm{~Bq} \mathrm{~m}^{-3}$ (Wada et al., 2010).

The concentrations of $\mathrm{CO}$ were measured continuously by using a nondispersive infrared analyzer (NDIR: GA-360S, Horiba, Ltd., Japan) with an overall analytical precision of $\pm 5 \mathrm{ppb}$. The measuring system was changed to a gas chromatograph (TRA-1 Round Science Inc.), with an overall precision of \pm 2 ppb, since 2008, 2009, and 2010 at YON, RYO, and MNM, respectively. The standard gases to calibrate the analyzers are traceable to the WMO mole fraction scale.

\subsection{3-D chemical transport model}

A 3-D global chemical transport model named Simulator of Trace Atmospheric constituent on a Global scale (STAG) developed at the AIST (Taguchi, 1996; Taguchi et al., 2002a) was used in this study. This model, which consists of 28 sigma vertical levels with a horizontal resolution of $1.875^{\circ} \times 1.875^{\circ}$, was driven every $6 \mathrm{hrs}$ using the meteorological reanalysis data provided by the National Oceanic and Atmospheric Administration/the Cooperative Institute for Research in Environmental Sciences (NOAA/CIRES) Climate Diagnostics Center at their website (http://www.cdc. noaa.gov/). The boundary layer height at each time step in the model was determined by the bulk Richardson number (Troen and Mahrt, 1986) and a uniform distribution of trace gas concentrations was assumed in the boundary layer. The basic performance of the model was evaluated by using ${ }^{222} \mathrm{Rn}$ concentrations (Taguchi et al., 2002b).

The emanation rate of ${ }^{222} \mathrm{Rn}$ was given a value of 1.0 atoms $\mathrm{cm}^{-2} \mathrm{~s}^{-1}$ for all the land areas between $60^{\circ} \mathrm{S}$ and $60^{\circ} \mathrm{N}$, and 0.5 atoms $\mathrm{cm}^{-2} \mathrm{~s}^{-1}$ for the land areas between $60^{\circ} \mathrm{N}$ and $70^{\circ} \mathrm{N}$, excluding Greenland, with no temporal variation (Jacob et al., 1997; Taguchi et al., 2002b, 2011). The emanation rate of ${ }^{222} \mathrm{Rn}$ from the ocean was set to 0 atoms $\mathrm{cm}^{-2} \mathrm{~s}^{-1}$, since our study focused on the short term variations in atmospheric ${ }^{222} \mathrm{Rn}$.

The CO emissions from all anthropogenic sources used in the model were obtained from the Emission Database for Global Atmospheric Research (EDGAR) version 4.1 (ECJRC/PBL, 2010). Biomass burning, however, was not included. The CO from photochemical production via the oxidation of $\mathrm{CH}_{4}$ and nonmethane hydrocarbons (NMHCs) were regarded as constant with a value of $40 \mathrm{ppb}$, a value based on the result of previous simulation studies (Liang et al., 2004; Takigawa et al., 2005). The photochemical destruction of $\mathrm{CO}$ with hydroxyl $(\mathrm{OH})$ radical was included in the model as the only CO sink. The rate coefficient of this photochemical destruction was obtained from Atkinson et al. (2006). The concentration of $\mathrm{OH}$ radical was obtained from the climatological seasonal fields published by Spivakovsky et al. (2000).

\section{Results}

\subsection{Observational data of the atmospheric $\mathrm{CO}$ and ${ }^{222} \mathbf{R n}$}

Figure 2 shows the hourly mean concentrations of atmospheric CO observed at MNM, YON, and RYO located in the western North Pacific. As reported by Wada et al. (2011), all three stations reveal a distinct seasonal cycle accompanied by high-frequency synoptic variations, although the annual mean CO level is station dependent. The seasonal cycle shows a minimum during the summer season from July to 


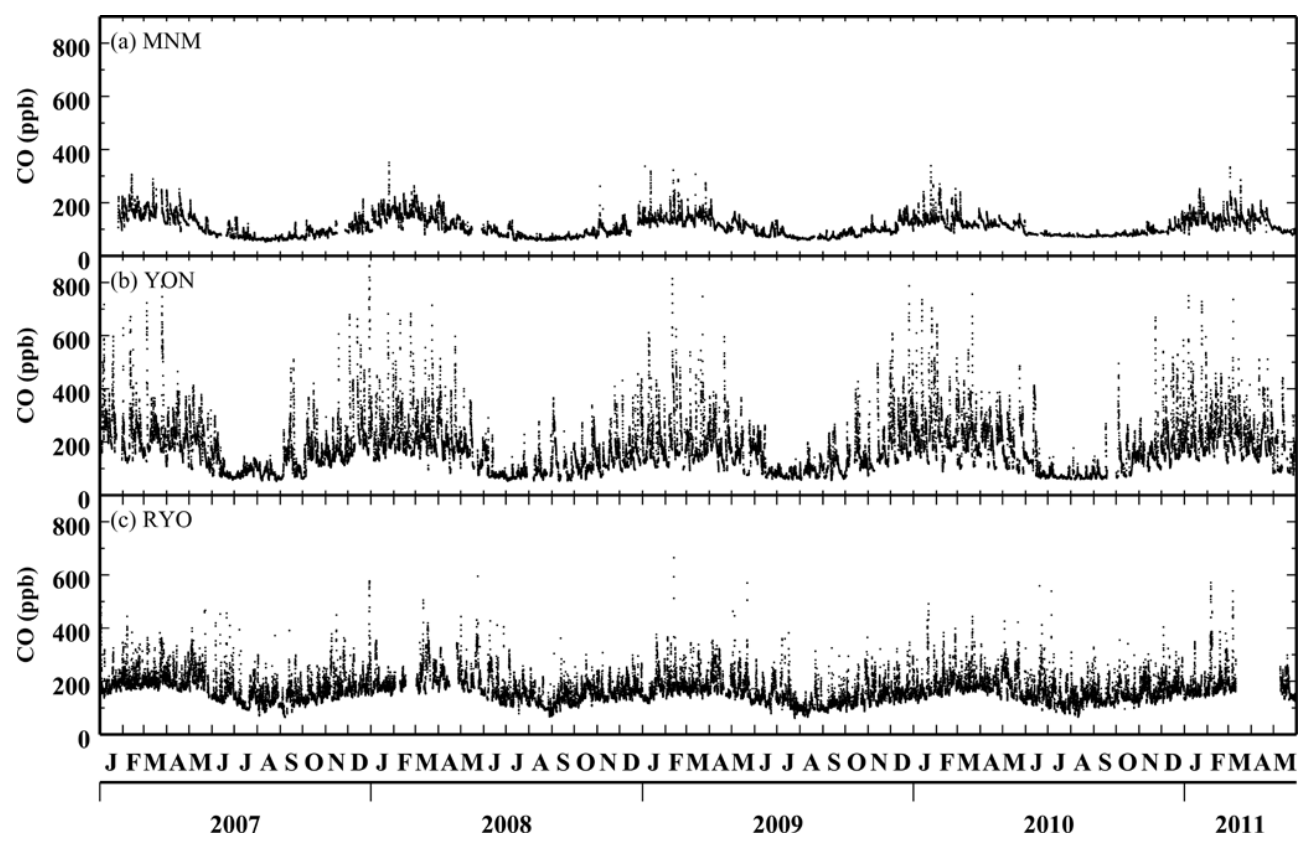

Fig. 2. Hourly mean observed data of the atmospheric CO concentration at MNM (a), YON (b), and RYO (c).

August and a maximum during the winter season from January to March. The synoptic variations consisting of episodically enhanced CO peaks on timescales less than one week are clearly revealed at all three stations, although their frequencies and magnitudes are different from each other. It has already been demonstrated by various modeling studies that major high $\mathrm{CO}$ concentration peaks observed at these stations are usually caused by the transport of Asian pollutions emitted mainly from China, Korea and Japan (Liang et al., 2004; Takigawa et al., 2005; Sawa et al., 2007).

Figure 3 shows the hourly mean concentrations of atmospheric ${ }^{222} \mathrm{Rn}$ observed at MNM, YON, and RYO. The temporal variations of ${ }^{222} \mathrm{Rn}$ at all three stations show, as was the case with $\mathrm{CO}$, a distinct seasonal cycle accompanied by highfrequency synoptic variations. No significant long-term trend was found at any of the stations. The difference in the magnitude of the ${ }^{222} \mathrm{Rn}$ concentration among the three stations is related to their respective geographical locations with different distances from the continental ${ }^{222} \mathrm{Rn}$ source regions. The seasonal cycles observed at MNM and YON are similar, with a maximum in the winter season around DecemberJanuary and a minimum in the summer season around JulySeptember. In contrast, a different pattern of seasonal cycle at RYO was found, reflecting a strong influence from local ${ }^{222} \mathrm{Rn}$ source emissions in a complex terrain surrounding the station.

No significant diurnal cycle was found at both MNM and YON, indicating no impact of local emissions on the ${ }^{222} \mathrm{Rn}$ measurements at these island stations. Thus, the numerous synoptic variations observed at MNM and YON were likely influenced by the long range transport of air masses from the
Asian continent. In contrast, the distinct diurnal cycle was observed at RYO with a maximum in the early morning and a minimum in the afternoon. This behavior is consistent with the diurnal cycle in the venting rate associated with the planetary boundary layer (PBL) height over inland regions (Moses et al., 1960; Servant, 1966; Chambers et al., 2009). These results support a strong local influence on the ${ }^{222} \mathrm{Rn}$ measurements at RYO from the nighttime inversion.

\subsection{Enhanced ${ }^{222}$ Rn events}

The observed concentrations of ${ }^{222} \mathrm{Rn}$ at three stations reveal numerous synoptic variations consisting of episodically enhanced ${ }^{222} \mathrm{Rn}$ peaks on timescales less than one week (Fig. 3). These peaks are consistent with the transport of continental air masses since no local sources were found that would produce similar peaks, although RYO measurements are influenced by local sources. Based on the preliminary results obtained at MNM, these ${ }^{222} \mathrm{Rn}$ peaks showed a high correlation with synoptic scale variation of $\mathrm{CO}$ observed simultaneously at this station (Wada et al., 2010).

Figure 4 shows the detailed variations of ${ }^{222} \mathrm{Rn}$ observed at MNM, YON, and RYO during January 2010, compared with those of observed concentrations of atmospheric CO. During the month, 10, 9, and 4 enhanced ${ }^{222} \mathrm{Rn}$ events were identified at MNM, YON, and RYO, respectively. Corresponding increase in $\mathrm{CO}$ during each enhanced ${ }^{222} \mathrm{Rn}$ event is also shown in the figure. This ${ }^{222} \mathrm{Rn}$-CO relationship was also observed at all three stations for other months during our study period. Each event corresponded to a cold frontal passage over the station, in a similar process described by Sawa et 


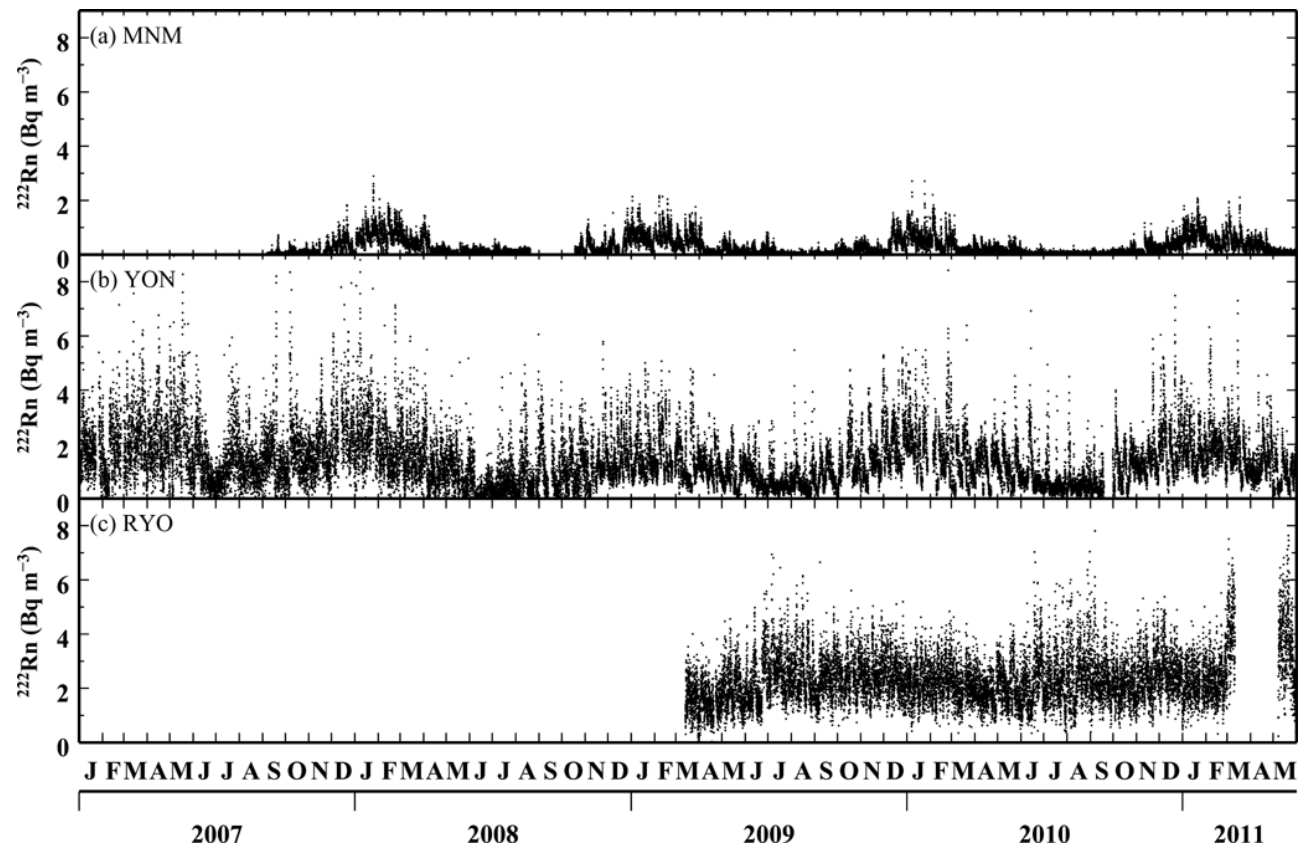

Fig. 3. Hourly mean observed data of the atmospheric ${ }^{222}$ Rn concentration at MNM (a), YON (b), and RYO (c).

(a) MNM

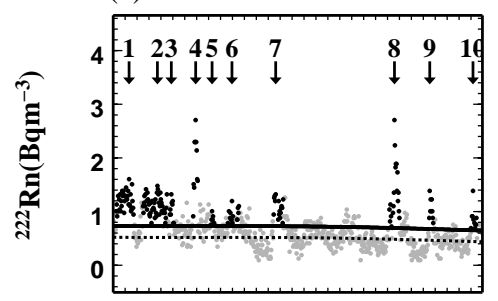

(b) YON
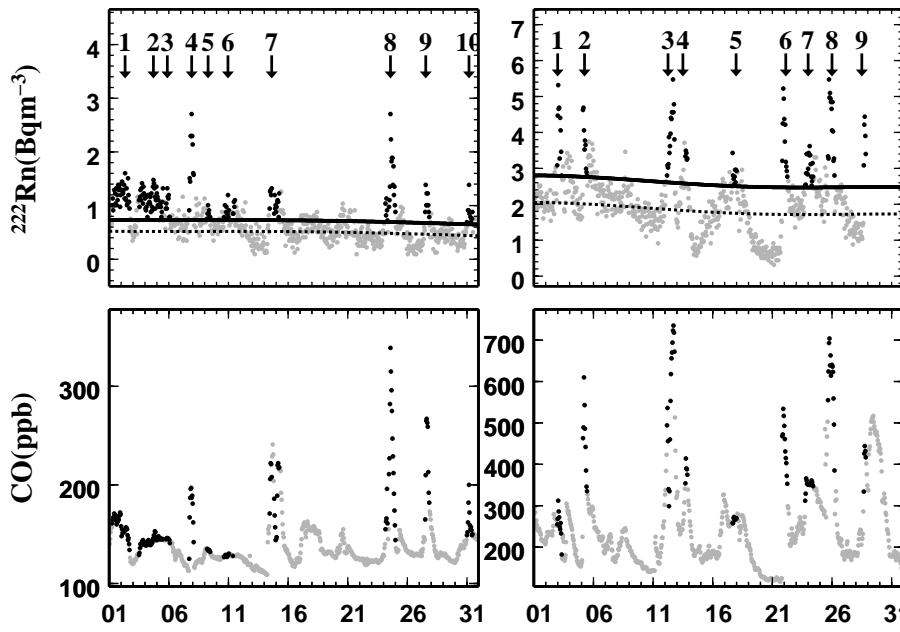

Day of Jan 2010

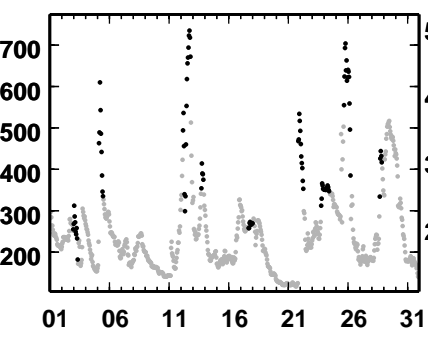

Day of Jan 2010 (c) RYO
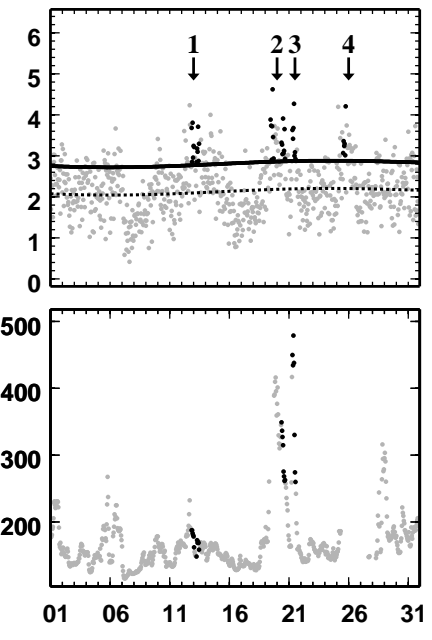

Day of Jan 2010

Fig. 4. Typical synoptic scale variation of hourly mean concentrations of atmospheric ${ }^{222} \mathrm{Rn}$ and CO observed at MNM (a), YON (b), and RYO (c) in January 2010. Arrows represent the peak of each enhanced ${ }^{222} \mathrm{Rn}$ event. The dashed and the solid lines for ${ }^{222} \mathrm{Rn}$ (top panel) are the smoothed fitting curve and the upper threshold of $\Delta \mathrm{Rn}$, respectively. The black and gray dots represent the $\Delta \mathrm{Rn}$ data defined as enhanced and non-enhanced events, respectively (see text). The black dots for CO relate to the corresponding periods of the enhanced ${ }^{222} \mathrm{Rn}$ events.

al. (2007) in which well-mixed polluted air masses with high concentrations of $\mathrm{CO}$ from the Asian continent are transported to the western North Pacific.

We identified the enhanced ${ }^{222} \mathrm{Rn}$ peaks as deviations from a fitted curve obtained by applying the 26th Butterworth filter with a 30-day low pass filter cut-off, a procedure described in Wada et al. (2011). The differences between the hourly observed data and the smoothed seasonal curve were calculated as residual ${ }^{222} \mathrm{Rn}(\Delta \mathrm{Rn})$, and are plotted in Fig. 4. Positive $\Delta R n$ peaks that were identified as enhanced ${ }^{222} \mathrm{Rn}$ (ERN) events were chosen based on the following criteria: (1) $\Delta \mathrm{Rn} \geq 2 \sigma$ from the fitted curve, where $\sigma$ is the standard deviation calculated from the negative $\Delta \mathrm{Rn}$ in each month, and (2) $\Delta \mathrm{Rn}$ lasted for more than four hours. Following these 

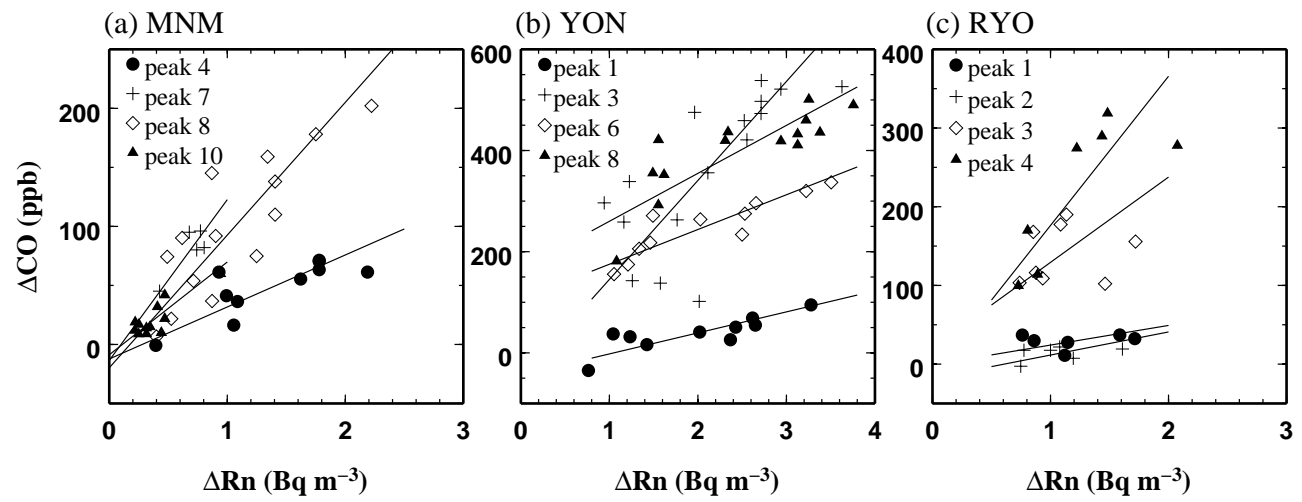

Fig. 5. Typical scatter plots of $\Delta C O$ as a function of $\Delta \mathrm{Rn}$ observed at MNM (a), YON (b), and RYO (c) in January 2010. The solid line represents the RMA regression for each event. The peak numbers correspond to those in Fig. 4. Note that the $\mathrm{x}$ and $\mathrm{y}$ axis are different in each figure.

criteria, 290, 516, and $148 \mathrm{ERN}$ events were identified in the MNM data (September 2007-May 2011), in the YON data (February 2006-May 2011), and in the RYO data (March 2009-May 2011), respectively.

\subsection{Correlation of observed $\mathrm{CO}$ with ${ }^{222} \mathrm{Rn}$}

In order to determine the enhancement ratios of $\mathrm{CO}$ and ${ }^{222} \mathrm{Rn}$, slopes of $\Delta \mathrm{Rn}$ with $\Delta \mathrm{CO}$ were calculated for each ERN event. $\triangle \mathrm{CO}$ was determined by the same procedure that was used to determine $\Delta \mathrm{Rn}$. Figure 5 shows some examples of the enhanced $\mathrm{CO}$ correlations and their slopes for the ERN events observed at MNM, YON, and RYO in January 2010. Since high correlations between $\mathrm{CO}$ and ${ }^{222} \mathrm{Rn}$ were found for the ERN events, their slopes were obtained by using the reduced major axis (RMA) regression (Hirsch and Gilroy, 1984). The slope of the enhanced values is denoted as $\Delta \mathrm{CO} / \Delta \mathrm{Rn}$. Note that the units of $\Delta \mathrm{CO} / \Delta \mathrm{Rn}$ are in $\mathrm{ppb}\left(\mathrm{Bq} \mathrm{m}^{-3}\right)^{-1}$.

$\Delta \mathrm{CO} / \Delta \mathrm{Rn}$ obtained at MNM varied with each $\mathrm{ERN}$ event. These differences were found to be dependent on the transit time of the air masses from the Asian continent to MNM and the ${ }^{222} \mathrm{Rn}$ decay during the transport (Wada, 2011). The variation in $\Delta \mathrm{CO} / \Delta \mathrm{Rn}$ from ERN event to ERN event at MNM was about $10.8 \%$ after correcting for the ${ }^{222} \mathrm{Rn}$ decay during transport. These results indicate that the air masses reaching MNM from the continental Asia are well mixed by the time they reach the station. On the other hand, $\Delta \mathrm{CO} / \Delta \mathrm{Rn}$ at YON varied noticeably even though the ${ }^{222} \mathrm{Rn}$ decay correction was negligible due to short transit times of the air mass transport (Wada et al., 2011). The variation, therefore, is likely attributable to the variation in the sources themselves. In comparison, the ERN events at RYO were not that many and the $\Delta \mathrm{CO}-\Delta \mathrm{Rn}$ correlation was significantly low, due likely to the influence of local sources and the complex terrain around the station.

\subsection{Model simulation of the atmospheric ${ }^{222} \mathrm{Rn}$ and $\mathrm{CO}$}

${ }^{222} \mathrm{Rn}$ concentration was simulated by using the global chemical transport model STAG. Figure 6 shows a comparison of simulated ${ }^{222} \mathrm{Rn}$ concentration in the surface layer with the observed data of 6 hourly means at MNM, YON, and RYO for 2010. The model was generally successful in reproducing the seasonal variations observed at all three stations. The simulated summer ${ }^{222} \mathrm{Rn}$ at MNM showed low values of less than $0.2 \mathrm{~Bq} \mathrm{~m}^{-3}$, consistent with the observed concentrations at the station. At YON, the observed ${ }^{222} \mathrm{Rn}$ values in the winter and spring seasons were well simulated by the model, althogh the simulated ${ }^{222} \mathrm{Rn}$ was little lower than the observation in the summer due likely to subgrid scale emissions of ${ }^{222} \mathrm{Rn}$ along the east coast of China. The simulated seasonal cycle at both YON and MNM agreed well with the observation. In this study, the model calculations were carried out by using a time invariant and spatially uniform ${ }^{222} \mathrm{Rn}$ flux density, although it has been reported that the ${ }^{222} \mathrm{Rn}$ fluxes over the continent do vary with time and space mainly due to changes in the soil water content (Dörr and Munnich, 1990; Genthon and Armengaud, 1995). The consistency between the model and the observation in this study indicated that the ${ }^{222} \mathrm{Rn}$ flux density employed in the model was adequate for reproducing the observed ${ }^{222} \mathrm{Rn}$ concentration at these stations. However, in order to estimate the impact of uncertainty in the ${ }^{222} \mathrm{Rn}$ flux density on our CO emission estimates, we conducted an additional simulation using the simulated results of the monthly mean flux density of ${ }^{222} \mathrm{Rn}\left(60^{\circ} \mathrm{E}-150^{\circ} \mathrm{E}, 20^{\circ} \mathrm{N}-70^{\circ} \mathrm{N}, 1^{\circ} \times 1^{\circ}\right)$ from 2007 to 2010 calculated by Hirao et al. (2010). As we will show in Sect. 3.7, the impact was minimal.

The model was also able to identify all the major enhanced ${ }^{222} \mathrm{Rn}$ events in the synoptic scale variation observed at the stations, particularly in terms of the timing of the occurrences of these ERN events. However, the model slightly 


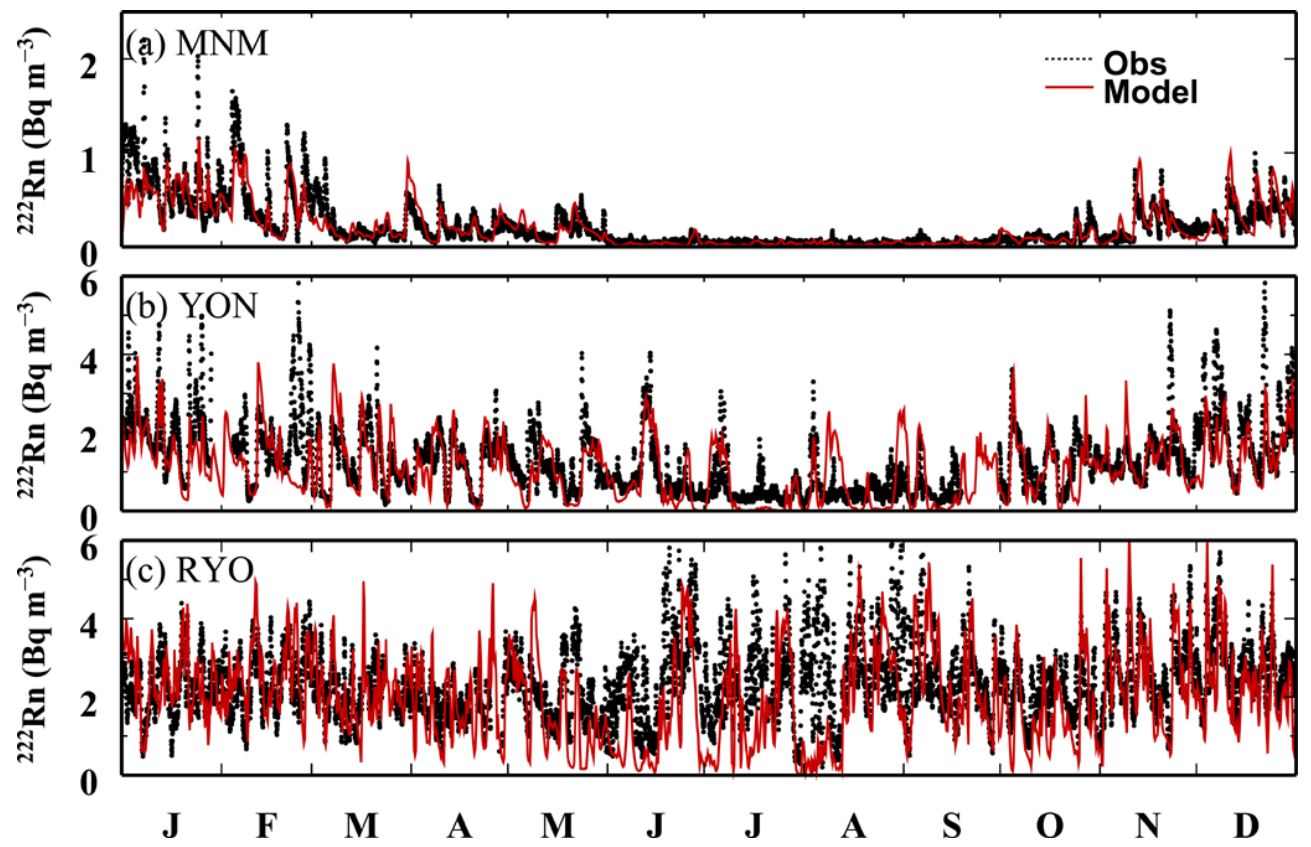

Fig. 6. Simulated and observed atmospheric concentration of ${ }^{222} \mathrm{Rn}$ at MNM (a), YON (b), and RYO (c) in 2010 . The black dots represent 6 hourly mean observed ${ }^{222} \mathrm{Rn}$ and the red solid line represents simulated ${ }^{222} \mathrm{Rn}$.

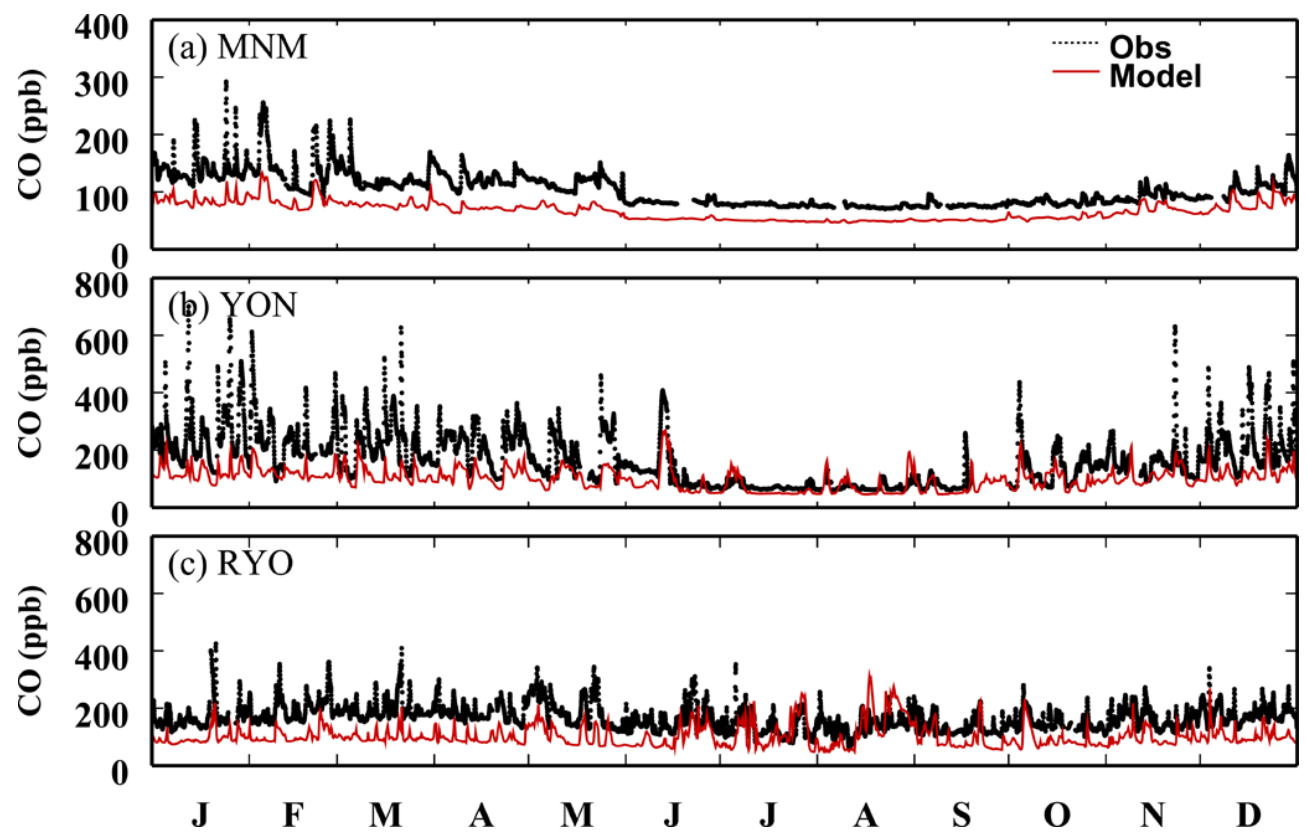

Fig. 7. Simulated and observed atmospheric concentration of CO at MNM (a), YON (b), and RYO (c) in 2010. The black dots represent 6 hourly mean observed $\mathrm{CO}$ and the red solid line represents simulated CO.

underestimated the magnitude of the ${ }^{222} \mathrm{Rn}$ enhancement, probably due to the coase spatial resolution of the model.

The simulation of $\mathrm{CO}$ was carried out by using the same model used for the simulation of ${ }^{222} \mathrm{Rn}$. Figure 7 shows a comparison of simulated $\mathrm{CO}$ concentration in the surface air with the observed data of 6 hourly means at MNM, YON, and RYO for 2010. The model was successful in reproducing the observed seasonal cycle, the synoptic variations, and the enhanced CO peaks at these stations. Although the model underestimated the observed ${ }^{222} \mathrm{Rn}$ peaks, its underestimation of the observed $\mathrm{CO}$ peaks proved to be much more significant. 

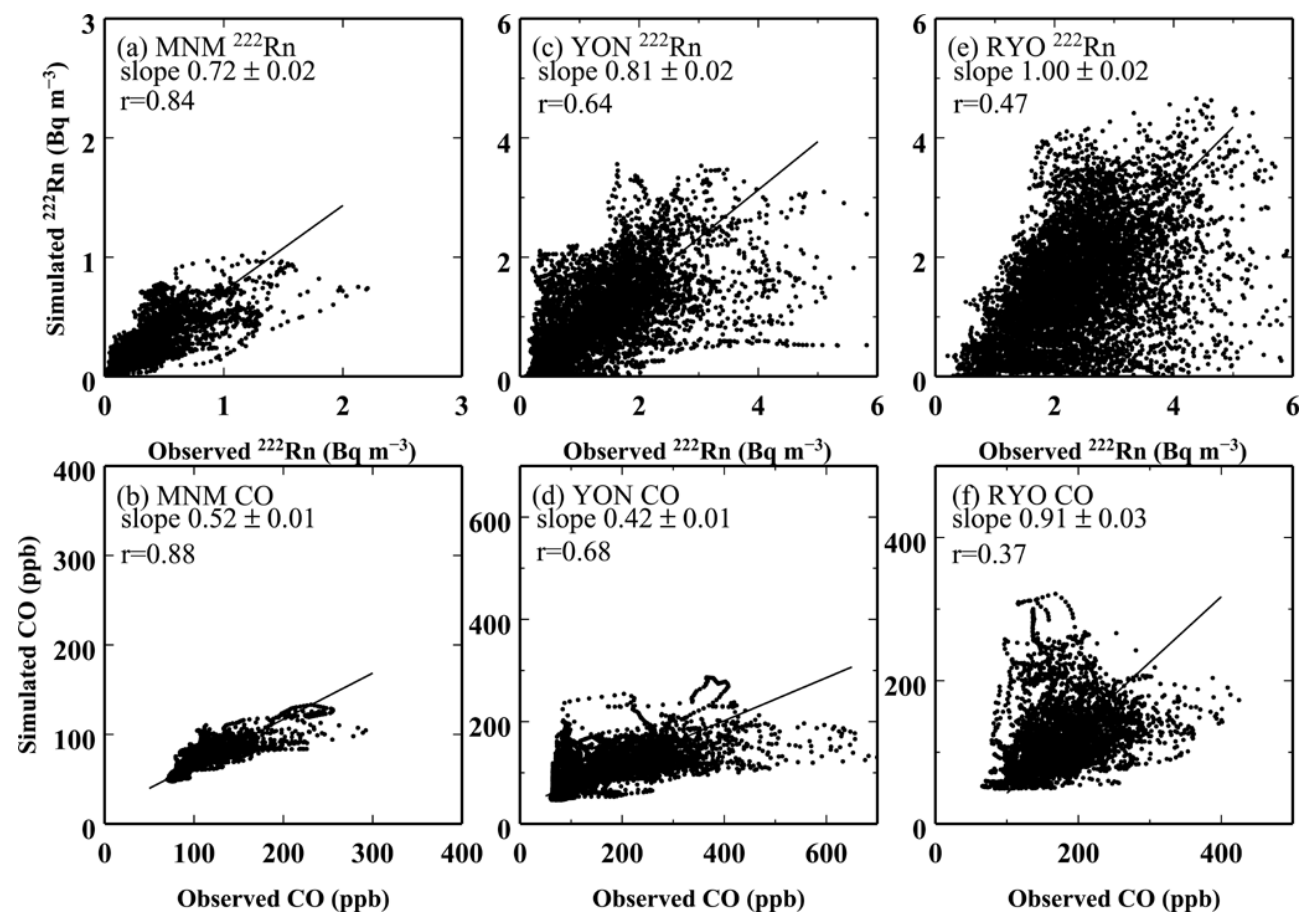

Fig. 8. Correlations between simulated results and observed data for ${ }^{222} \mathrm{Rn}$ and CO in 2010 for MNM, YON, and RYO. The solid lines represent the RMA regressions. The slopes are calculated by the RMA regression with $95 \%$ confidence interval obtained by the bootstrap method. The $r$ values represent correlation coefficients.

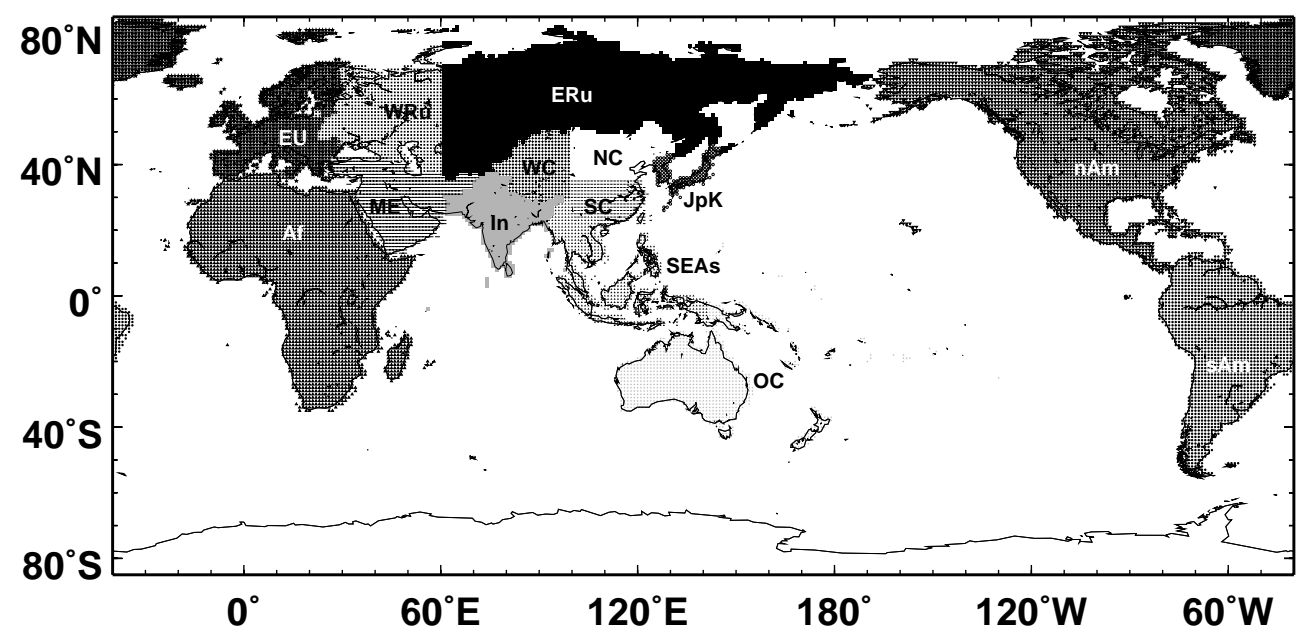

Fig. 9. Regions divided into 14 sectors for the tagged tracer model experiment. JpK; Japan and Korea, NC; North China, SC; South China, WC; West China, SEAs; Southeast Asia, In; India, OC; Oceania, ERu; East Russia, WRu; West Russia, ME; Middle East, EU; Europe, Af; Africa, nAm; North America, sAm; South America.

\subsection{Relationship between observed data and simulated results for $\mathrm{CO}$ and ${ }^{222} \mathrm{Rn}$}

Figure 8 shows the relationships between the observed 6 hourly mean concentration values and their simulated results for ${ }^{222} \mathrm{Rn}$ and $\mathrm{CO}$ for 2010 at the three stations. The correlation plots for ${ }^{222} \mathrm{Rn}$ show that the overall ratios of model/observation are about $0.72-1.00$, with a $95 \%$ confi- dence interval of 0.02 calculated by the bootstrap method (e.g. Xiao et al., 2004), resulting mainly from the model underestimation of large ${ }^{222} \mathrm{Rn}$ peaks within subgrid scale variations. The data at MNM showed a compact relation with a high correlation coefficient of 0.84 , while lower correlation coefficients of 0.64 and 0.47 were found at YON and RYO. Most of the major ERN events observed at all the stations 
throughout the year were captured by this model simulation. However, the correlation plots for $\mathrm{CO}$ at MNM and YON indicate that the model underestimated the observed $\mathrm{CO}$, more significantly than for ${ }^{222} \mathrm{Rn}$, due to the underestimated $\mathrm{CO}$ emissions in the EDGAR database that was used to drive the model $\mathrm{CO}$ field. This problem in the EDGAR database was also pointed out by several previous modeling studies (e.g. Kiley et al., 2003; Arellano, 2004; Ma and van Aardenne, 2004). Previous studies on the combustion ratio of $\mathrm{CO} / \mathrm{CO}_{2}$ observed around the western North Pacific indicated that YON is influenced mostly by the emissions from China where anthropogenic emissions have been significantly underestimated (e.g. Palmer et al., 2003; Heald et al., 2004). On the other hand, RYO is influenced mostly by the regional sources in Japan, while MNM is influenced by the sources distributed over a much greater areas in East Asia (Wada et al., 2011). Therefore, the emission of CO from the regions detected at the stations MNM and YON are significantly underestimated when compared with that of RYO.

Among all the stations, MNM is located farthest from the continental East Asia. It therefore "sees" CO emissions from a wider geographical region in East Asia than the other stations. Combined with the fact that $\mathrm{CO}$ and ${ }^{222} \mathrm{Rn}$ are highly correlated at MNM, we used the observed and simulated data at MNM to obtain a more realistic estimate of the $\mathrm{CO}$ emission from East Asia than before.

\subsection{Estimation procedure based on the radon tracer method}

The radon tracer method has been mainly applied to inland sites in European. We applied the method to our sites in the western North Pacific region. The basic concept of our method is that the enhancement ratio of $\mathrm{CO} /{ }^{222} \mathrm{Rn}$ associated with each ERN event shows agreement between the model and the observation when the emission database used in the model is realistic. Error in either the $\mathrm{CO}$ or ${ }^{222} \mathrm{Rn}$ emission in the model can produce disagreement with the observed $\mathrm{CO} / 222 \mathrm{Rn}$ ratio. In our study, the model simulated the observed ${ }^{222} \mathrm{Rn}$ well. Therefore, any difference between the modeled and the observed $\mathrm{CO} /{ }^{22} \mathrm{Rn}$ ratio can be traced to errors in the estimated $\mathrm{CO}$ emission in the model, which can be adjusted to bring the model simulation results closer to the observed. This way, we were able to obtain a more realistic estimate of the $\mathrm{CO}$ emission in East Asia by using the $\mathrm{CO} / 222 \mathrm{Rn}$ ratio. It should be noted that the uncertainty in the model transport was viewed as not being a significant issue because the same transport model was used to simulate both $\mathrm{CO}$ and ${ }^{222} \mathrm{Rn}$.

We conducted a tagged tracer experiment to adjust the simulated $\mathrm{CO}$ so that the simulated $\mathrm{CO} / 222 \mathrm{Rn}$ ratio would match the observed ratio. The adjustment is expressed as a cost function by which the CO emission is optimized (e.g. Suntharalingam et al., 2004). Figure 9 shows the regions used for the tagged tracer experiment. The global emission area is divided into 14 regions. China was divided into 3 regions of North China (NC), South China (SC), and West China (WC), with their boundaries defined by $100^{\circ} \mathrm{E}$ longitude and $35^{\circ} \mathrm{N}$ latitude. Japan and Korea were combined into one region (JpK).

The adjusted simulated $\mathrm{CO}$ was obtained by the following equation;

$X_{\mathrm{CO}}^{\prime}=\sum_{i=1}^{n} k_{i} \mathrm{C}_{i}$

where $X_{\mathrm{CO}}^{\prime}$ represents the adjusted simulated $\mathrm{CO}$ at $\mathrm{MNM}$, $n$ is the number of regions (equal to 14 in our study), $\mathrm{C}_{i}$ is the simulated CO at MNM with influence from region $\mathrm{i}$ obtained by the tagged tracer experiment, and $k_{i}$ is the corrective coefficient for region $i$. These corrective coefficients were determined by minimizing the cost function which was defined in this study as a residual sum of squares between the observed and the simulated ratios associated with each ERN event. The cost function is described by the following equation;

$S=\sum_{j=1}^{m}\left(\left(\frac{X_{\mathrm{CO}}}{222 \mathrm{Rn}}\right)_{j}^{\text {observed }}-\left(\frac{X_{\mathrm{CO}}^{\prime}}{222 \mathrm{Rn}}\right)_{j}^{\text {simulated }}\right)^{2}$.

where $S$ is the residual sum of squares and $\mathrm{m}$ is the number of ERN events. Through changing the corrective coefficients of $k_{i}$ in Eq. (1), optimized pairs of $k_{i}$ are obtained by minimizing $\mathrm{S}$ in Eq. (2).

\subsection{Estimates of $\mathrm{CO}$ emission in East Asia}

Figure 10 shows the results of the tagged tracer experiment for CO. The shaded areas represent simulated ERN events for the peaks 1, 4, 7, 8, 9, and 10 of the observed ERN events shown in Fig. 4. Other peaks were not well reproduced, probably because these events were relatively small. The figure shows that the synoptic scale variation of atmospheric $\mathrm{CO}$ at MNM was influenced by the three regions of NC, SC, and $\mathrm{JpK}$, while other regions were negligible. The $\mathrm{CO}$ emission at MNM from biomass burning in Southeast Asia was also deemed negligible based on the results of an additional $\mathrm{CO}$ simulation by using biomass burning emission of GFED ver. 3.1 from 2005 to 2010 (van der Werf et al., 2010) as a driver for the CO field in STAG. Consequently, the corrective coefficients in Eq. (1) for the regions $\mathrm{NC}, \mathrm{SC}$ and JpK were adjusted to optimize the $\mathrm{CO}$ emissions in the model, whereas the corrective coefficients for other 11 regions were fixed to be 1 .

To perform calculations using Eq. (2), the ERN events observed from November to April were selected in order to ensure the influence of cold-front transport mechanism for all the events. In addition, the ERN events were characterized by high correlation between enhanced $\mathrm{CO}$ and ${ }^{222} \mathrm{Rn}$ for both the observed and simulated results, ensuring pollution events 


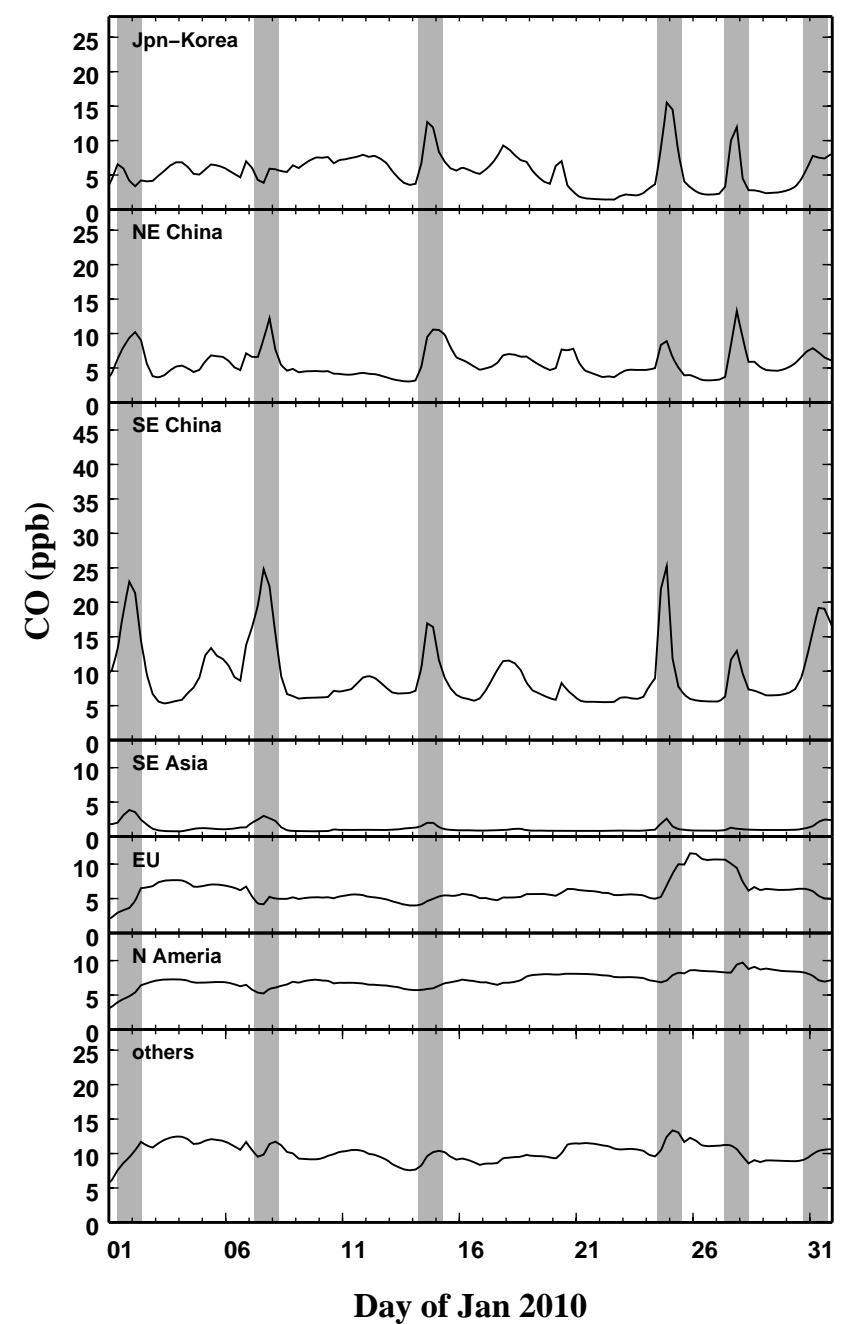

Fig. 10. Simulated results of the tagged tracer experiment for atmospheric $\mathrm{CO}$ at MNM. The gray shaded areas represent the enhanced $\mathrm{CO}$ events for peak $1,4,7,8,9$, and 10 of the observed data in Fig. 4.

with well mixed air masses. Twenty ERN events with correlation coefficients of more than 0.7 were found, constituting about $11.2 \%$ of the identified ERN events during November to April. With these $20 \mathrm{ERN}$ events, the corrective coefficients for the regions of $\mathrm{NC}, \mathrm{SC}$, and $\mathrm{JpK}$ were determined by changing each corrective coefficient from 0.5 to 3.0. From the results of the optimization, the corrective coefficients for $\mathrm{NC}, \mathrm{SC}$, and JpK were determined to be 2.8, 1.4, and 1.1, respectively. Figure 11 shows an example of the correlation between $\mathrm{CO}$ and ${ }^{222} \mathrm{Rn}$ for the ERN event on 23 November in 2009 , for both the observation and the simulation. In this figure, a priori ratio of $\mathrm{CO} /{ }^{222} \mathrm{Rn}$ calculated by the model was significantly smaller than the observed ratio due to the aforementioned underestimation of the $\mathrm{CO}$ emission in East Asia, whereas a posteriori ratio improved after adjusting the $\mathrm{CO}$ emissions in the 3 regions. The adjustment resulted in a new
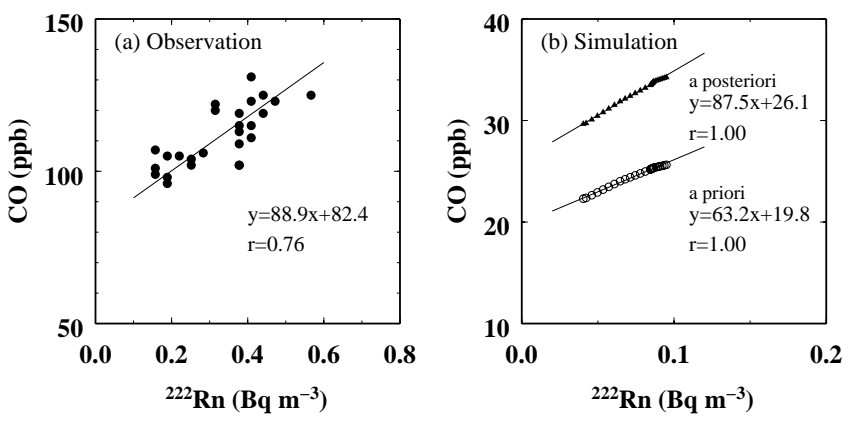

Fig. 11. An example of correlations between $\mathrm{CO}$ and ${ }^{222} \mathrm{Rn}$ for the enhanced ${ }^{222} \mathrm{Rn}$ event on 23 November in 2009 from the observation (a) and simulations (b) with a priori (open circles) and a posteriori (solid triangles) emissions, respectively. The solid lines represent the RMA regressions and the $r$ values represent correlation coefficients.

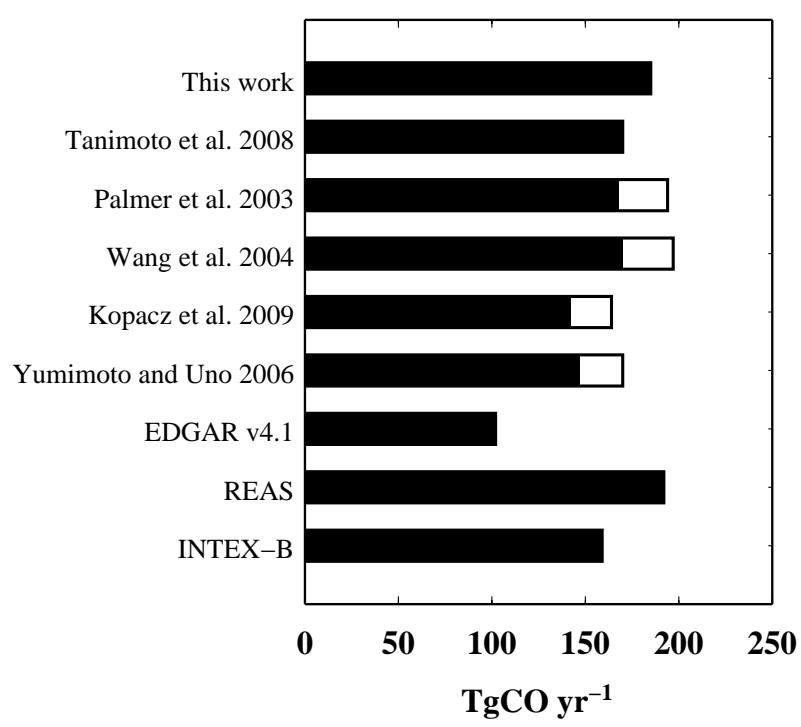

Fig. 12. The estimated emission of $\mathrm{CO}$ in China. The solid bars represent data in Table 1, and the open bars represent estimated values for the reference year of 2005 by assuming an increase of $16 \%$ during 2001-2005.

emission estimate of $203 \mathrm{Tg} \mathrm{CO} \mathrm{yr}^{-1}$ for China, Japan, and Korea, with $185 \mathrm{Tg} \mathrm{CO} \mathrm{yr}^{-1}$ attributed to China. The original emission given in the EDGAR ver. 4.1 database for China was $102 \mathrm{TgCO} \mathrm{yr}^{-1}$, which is about $45 \%$ smaller than our emission estimate. Although the criterion for selecting an ERN event was based arbitrarily on the correlation coefficient being greater than 0.7 , changing the criterion from 0.6 to 0.8 resulted in one standard deviation variability of only $8.3 \%$ in emission estimates.

As mentioned earlier, in order to estimate the impact of uncertainty in the ${ }^{222} \mathrm{Rn}$ flux density on our CO emission estimation, we conducted a simulation using the ${ }^{222} \mathrm{Rn}$ flux density obtained by Hirao et al. (2010) to drive our transport model, instead of the constant ${ }^{222} \mathrm{Rn}$ flux of 
Table 1. Comparison of estimated CO emissions in East Asia.

\begin{tabular}{|c|c|c|c|c|c|}
\hline Method & Study & Sources $* *$ & $\mathrm{TgCO} \mathrm{yr}^{-1}$ & Regions & Reference year \\
\hline \multirow[t]{4}{*}{ Our Method } & This work & $\mathrm{FF} ; \mathrm{BF}$ & 203 & China, Japan, Korea & 2007-2011 \\
\hline & & & 185 & China & \\
\hline & Tanimoto et al. (2008) & $\mathrm{FF} ; \mathrm{BF} ; \mathrm{BB}$ & 170 & China & 2005 \\
\hline & Heald et al. (2004) & $\mathrm{FF} ; \mathrm{BF} ; \mathrm{BB}$ & 192 & China, Japan, Korea & 2001 \\
\hline \multirow[t]{9}{*}{ Inverse Method } & Palmer et al., 2003 & $\mathrm{FF} ; \mathrm{BF}$ & 194 & China, Japan, Korea & 2001 \\
\hline & & & 168 & China & \\
\hline & Wang et al., 2004 & $\mathrm{FF} ; \mathrm{BF} ; \mathrm{BB}$ & 170 & China & 2001 \\
\hline & Kopacz et al., 2009 & $\mathrm{FF} ; \mathrm{BF} ; \mathrm{BB}$ & 156 & China, Japan, Korea & 2001 \\
\hline & & & 142 & China & \\
\hline & Yumimoto and Uno (2006) & $\mathrm{FF} ; \mathrm{BF}$ & 147 & China & 2001 \\
\hline & Arellano (2004) & $\mathrm{FF} ; \mathrm{BF}$ & 205 & China, Japan, Korea & 2000 \\
\hline & EDGAR v4.1 & $\mathrm{FF} ; \mathrm{BF}$ & $118^{*}$ & China, Japan, Korea & 2005 \\
\hline & & & $102^{*}$ & China & \\
\hline \multirow[t]{4}{*}{ Bottom-Up Emission } & REAS & $\mathrm{FF} ; \mathrm{BF}$ & $206^{*}$ & China, Japan, Korea & 2005 \\
\hline & & & $192^{*}$ & China & \\
\hline & INTEX-B & $\mathrm{FF} ; \mathrm{BF}$ & $170^{*}$ & China, Japan, Korea & 2006 \\
\hline & & & $159^{*}$ & China & \\
\hline
\end{tabular}

* These values were summed in each region defined in this study.

** FF; fossil fuel BF; Biofuel combustion BB; biomass burning.

1.0 atom $\mathrm{cm}^{-2} \mathrm{~s}^{-1}$. The difference in the estimated results for the $\mathrm{CO}$ emission in China between using the constant ${ }^{222} \mathrm{Rn}$ flux and the heterogeneous flux of Hirao et al. (2010) came out to be only $3.2 \%$.

Considering the variation in the observed enhancement ratio, in the distribution of the ${ }^{222} \mathrm{Rn}$ flux density, and in the selection process of an ERN event, we estimated an overall error of our method to be about $14 \%$.

\subsection{Comparison of $\mathrm{CO}$ emission estimates}

Table 1 shows a comparison of the $\mathrm{CO}$ emission for East Asia obtained in this study with the emission estimates from several inversion and bottom-up methods. Although some estimated values include biomass burning emission, they all can be compared with each other because the biomass burning is not a significant source in China. The contribution of the biomass burning emission in China was reported as $6.7 \%$ (Palmer et al., 2003) and $7.9 \%$ (Heald et al., 2004) of the total CO emission.

Our study shows that $91 \%$ of the total emission for East Asia comes from China. The remainder comes from Japan and Korea. This is consistent with the results of Palmer et al. (2003), Kopacz et al. (2009), and three bottom-up emissions. There are however, large variations in the emission estimates within each method, as well as between methods. Among the bottom-up methods, the EDGAR database shows the greatest underestimation. The variation among the inverse methods could be attributable to an increase in the emission during 2001 to 2005. Tanimoto et al. (2008) reported that an increase in the $\mathrm{CO}$ emission in China from 2001 to 2005 was estimated to be about $16 \%$. We used this rate of increase to adjust all the emission estimates listed in Table 1 to a reference year of 2005. Figure 12 shows the estimated emissions of $\mathrm{CO}$ in China listed in Table 1 (solid bars) and their adjusted values to the reference year 2005 (open bars). From the figure, it can be seen that the EDGAR database shows a significant underestimation by about $45 \%$. All other estimates, including the one from this study, agree reasonably well with each other. Ohara et al. (2007) reported that the REAS database was consistent with the inverse estimates and those from the forward modeling, whereas Zhang et al. (2009) reported that the INTEX-B database was partially consistent with a forward modeling result (Chen et al., 2009) at a suburban area near Beijing but underestimated in the Beijing urban area.

\section{Conclusions}

Atmospheric concentrations of $\mathrm{CO}$ and ${ }^{222} \mathrm{Rn}$ were observed continuously at Minamitorishima (MNM), Yonagunijima (YON), and Ryori (RYO) from 2007 to 2011. These measurements showed a seasonal cycle with a winter maximum and a summer minimum in both $\mathrm{CO}$ and ${ }^{222} \mathrm{Rn}$. In addition, high-frequency synoptic variations associated with enhanced ${ }^{222} \mathrm{Rn}$ (ERN) events due to long-range transport of continental air masses were well captured by the station measurements.

The enhancements of $\mathrm{CO}$ associated with increased ${ }^{222} \mathrm{Rn}$ were found in most of the ERN events at MNM, YON, and RYO. These simultaneous elevations indicate that the concentrations of ${ }^{222} \mathrm{Rn}$ and $\mathrm{CO}$ were well mixed in the pollutant air masses over the continent and were exported to 
the western North Pacific region by the way of cold frontal transport. The correlation of ${ }^{222} \mathrm{Rn}$ and $\mathrm{CO}$ during each ERN event observed at MNM was very high, with very little variation in the $\mathrm{CO} / 222 \mathrm{Rn}$ ratio from event to event during the winter. The correlation at YON was also high during the winter and spring, but the ratio varied from event to event due to the station's vicinity to the source regions, whereas the ratio at RYO was significantly low due to influence from local sources located in a complex terrain.

The chemical transport model STAG reproduced well the observed ${ }^{222} \mathrm{Rn}$ when forced with a constant and uniform flux density of 1.0 atom $\mathrm{cm}^{-2} \mathrm{~s}^{-1}$. The simulated seasonal cycles and synoptic scale variations were in good agreement with the observed. The model also reproduced well the timing of the synoptic scale variation of the observed $\mathrm{CO}$, but underestimated the magnitude of the variation. The ratios of the simulation/observation of $\mathrm{CO}$ were 0.52 and 0.42 at MNM and YON, respectively, whereas those of ${ }^{222} \mathrm{Rn}$ were 0.72 and 0.81 . The relatively low ratio values resulted from using in the model the EDGAR emission database that is known to have a significant underestimation of $\mathrm{CO}$ emission values over China.

A tagged tracer experiment of CO at MNM indicated that the synoptic variation of $\mathrm{CO}$ at $\mathrm{MNM}$ was influenced by the emissions in North China (NC), South China (SC), and Japan and Korea (JpK), with emissions from other regions found to be negligible in the winter and spring.

An estimation procedure based on the radon tracer method was developed and applied to the measurements from MNM. By optimizing the a priori emission of the EDGAR ver. 4.1 database for the ERN events observed at MNM during the winter and spring, the total anthropogenic $\mathrm{CO}$ emission from China, Japan, and Korea was estimated to be $203 \mathrm{Tg} \mathrm{CO} \mathrm{yr}^{-1}$, of which $91 \%$ originated in China. When compared with other estimated emissions of $\mathrm{CO}$ based on top-down and bottom-up methods, our estimated result was found to be in general agreement, except for the emission database of EDGAR ver. 4.1 which came out to be about $45 \%$ smaller than our emission estimate for China. These results strongly indicate that an independent method, such as the radon tracer method used in this study, to estimate emissions is important in East Asia where there is still large uncertainty associated with various estimates.

Acknowledgements. We would like to acknowledge all members of the Japan Meteorological Agency for operating ${ }^{222} \mathrm{Rn}$ and CO measuring systems at the stations of Minamitorishima, Yonagunijima, and Ryori. We also thank Ohara and Kurokawa for providing emission data base of REAS 2005. We are grateful to Yamazawa, Moriizumi, and Hirao for simulation of ${ }^{222} \mathrm{Rn}$ flux density. We wish to thank Higuchi (York University, Canada) for useful comments and discussion. We also thank the editor and two anonymous reviewers for their constructive comments. Our acknowledgements are extended to A. Kudo and C. Abe for produce of the ${ }^{222} \mathrm{Rn}$ measuring systems.
Edited by: M. K. Dubey

\section{References}

Akimoto, H.: Global air quality and pollution, Science, 302, 17161719, 2003.

Andreae, M. O., Berresheim, H., Andreae, T. W., Kritz, M. A., Bates, T. S., and Merrill, J. T.: Vertical distribution of dimethylsulfide, sulfur dioxide, aerosol ions, and radon over the northwest Pacific Ocean, J. Atmos. Chem., 6, 149-173, 1988.

Arellano Jr., A. F., Kasibhatla, P. S., Giglio, L., van der Werf, G. R., and Randerson, J. T.: Top-down estimates of global CO sources using MOPITT measurements, Geophys. Res. Lett., 31, L01104, doi:10.1029/2003GL018609, 2004.

Biraud, S., Ciais, P., Ramonet, M., Simmonds, P., Kazan, V., Monfray, P., O’Doherty, S., Spain, T. G., and Jennings, S. G.: European greenhouse gas emissions estimated from continuous atmospheric measurements and radon 222 at Mace Head, Ireland, J. Geophys. Res., 105, 1351-1366, 2000.

Biraud, S., Ciais, P., Ramonet, M., Simmonds, P., Kazan, V., Monfray, P., O’Doherty, S., Spain, T. G., and Jennings, S. J.: Quantification of Carbon Dioxide, Methane, Nitrous Oxide, and Chloroform emissions over Ireland from atmospheric observations at Mace Head, Tellus, 54, 41-60, 2002.

Chambers, S., Zahorowski, W., Matsumoto, K., and Uematsu, M.: Seasonal variability of radon-derived fetch regions for Sado Island, Japan, based on 3 years of observations: 2002-2004, Atmos. Environ., 43, 271-279, 2009.

Chen, D., Wang, Y., McElroy, M. B., He, K., Yantosca, R. M., and Le Sager, P.: Regional CO pollution and export in China simulated by the high-resolution nested-grid GEOS-Chem model, Atmos. Chem. Phys., 9, 3825-3839, doi:10.5194/acp-9-3825-2009, 2009.

Dörr, H. and Münnich, K. O.: ${ }^{222} \mathrm{Rn}$ flux and soil air concentration profiles in West-Germany. Soil ${ }^{222} \mathrm{Rn}$ as tracer for gas transport in the unsaturated soil zone, Tellus, 42B, 20-28, 1990.

European Commission, Joint Research Centre (JRC)/Netherlands Environmental Assessment Agency (PBL).: Emission Database for Global Atmospheric Research (EDGAR) release version 4.1, http://edgar.jrc.ec.europa.eu, 2010.

Genthon, C. and Armengaud, A.: Radon 222 as a comparative tracer of transport and mixing in two general circulation models of the atmosphere, J. Geophys. Res., 100, 2849-2866, doi:10.1029/94JD02846, 1995.

Heald, C. L., Jacob, D. J., Jones, D. B. A., Palmer, P. I., Logan, J. A., Streets, D. G., Sachse, G. W., Gille, J. C., Hoffman, R. N., and Nehrkorn, T.: Comparative inverse analysis of satellite (MOPITT) and aircraft (TRACE-P) observations to estimate Asian sources of carbon monoxide, J. Geophys. Res., 109, D23306, doi:10.1029/2004JD005185, 2004.

Hirao, S., Yamazawa, H., and Moriizumi, J.: Estimation of global radon exhalation rate distribution, Jpn. J. Health Phys., 45, 161171, 2010.

Hirsch, A. I.: On using radon-222 and $\mathrm{CO}_{2}$ to calculate regional-scale $\mathrm{CO}_{2}$ fluxes, Atmos. Chem. Phys., 7, 3737-3747, doi:10.5194/acp-7-3737-2007, 2007.

Hirsch, R. M. and Gilroy, E. J.: Methods of fitting a straight line to data: Examples in water resources, Water Resour. Bull., 20, 705-711, 1984. 
Hooghiemstra, P. B., Krol, M. C., Meirink, J. F., Bergamaschi, P., van der Werf, G. R., Novelli, P. C., Aben, I., and Röckmann, T.: Optimizing global CO emission estimates using a fourdimensional variational data assimilation system and surface network observations, Atmos. Chem. Phys., 11, 4705-4723, doi:10.5194/acp-11-4705-2011, 2011.

Husar, R. B., Tratt, D. M., Schichtel, B. A., Falke, S. R., Li, F., Jaffe, D., Gassó, S., Gill, T., Laulainens, N. S., Lu, F., Reheis, M. C., Chun, Y., Westphal, D., Holben, B. N., Gueymard, C., McKendry, I., Kuring, N., Feldman, G. C., McClain, C., Frouin, R. J., Merrill, J., DuBois, D., Vignola, F., Murayama, T., Nickovic, S., Wilson, W. E., Sassen, K., Sugimoto, N., and Malm, W. C.: Asian dust events of April 1998, J. Geophys. Res., 106, 18317-18330, doi:10.1029/2000JD900788, 2001.

Iida, T., Ikebe, Y., and Tojo, K.: An electrostatic radon monitor for measurements of environmental radon, Res. Lett. Atmos. Electr., 11, 55-59, 1991.

Iida, T., Ikebe, Y., Suzuki, K., Ueno, K., Wang, Z., and Jin, Y.: Continuous measurements of outdoor radon concentrations at various locations in East Asia, Environ. Int., 22, 139-147, 1996.

Jacob, D. J., Prather, M. J., Rasch, P. J., Shia, R. L., Balkanski, Y. J., Beagley, S. R., Bergmann, D. J., Blackshear, W. T., Brown, M., Chiba, M., Chipperfield, M. P., deGrandpre, J., Dignon, J. E., Feichter, J., Genthon, C., Grose, W. L., Kasibhatla, P. S., Kohler, I., Kritz, M. A., Law, K., Penner, J. E., Ramonet, M., Reeves, C. E., Rotman, D. A., Stockwell, D. Z., VanVelthoven, P. F. J., Verver, G., Wild, O., Yang, H., and Zimmermann, P.: Evaluation and intercomparison of global atmospheric transport models using ${ }^{222} \mathrm{Rn}$ and other short-lived tracers, J. Geophys. Res., 102, 5953-5970, 1997.

Kiley, C. M., Fuelberg, H. E., Palmer, P. I., Allen, D. J., Carmichael, G. R., Jacob, D. J., Mari, C., Pierce, R. B., Pickering, K. E., Tang, Y., Wild, O., Fairlie, T. D., Logan, J. A., Sachse, G. W., Shaack, T. K., and Streets, D. G.: An intercomparison and evaluation of aircraft-derived and simulated $\mathrm{CO}$ from seven chemical transport models during the TRACE-P experiment, J. Geophys. Res., 108, 8819, doi:10.1029/2002JD003089, 2003.

Kopacz, M., Jacob, D. J., Henze, D. K., Heald, C. L., Streets, D. G., and Zhang, Q.: Comparison of adjoint and analytical Bayesian inversion methods for constraining Asian sources of carbon monoxide using satellite (MOPITT) measurements of CO columns, J. Geophys. Res., 114, D04305, doi:10.1029/2007JD009264, 2009.

Kuhlmann, A. D., Worthy, D. E., Trivett, N. B. A., and Levin, I.: Methane emissions from a wetland region within the Hudson Bay Lowland: An atmospheric approach, J. Geophys. Res., 103, 16009-16016, 1998.

Levin, I., Glatzel-Mattheier, H., Marik, T., Cuntz, M., and Schmidt, M.: Verification of German methane emission inventories and their recent changes based on atmospheric observations, J. Geophys. Res., 104, 3447-3456, 1999.

Liang, Q., Jaeglé, L., Jaffe, D. A., Weiss-Penzias, P., Heckman, A., and Snow, J. A.: Long-range transport of Asian pollution to the Northeast Pacific: Seasonal variations and transport pathways of carbon monoxide, J. Geophys. Res., 109, D23S07, doi:10.1029/2003JD004402, 2004.

Ma, J. and van Aardenne, J. A.: Impact of different emission inventories on simulated tropospheric ozone over China: a region chemical transport model evaluation, Atmos. Chem. Phys., 4,
877-887, doi:10.5194/acp-4-877-2004, 2004.

Moses, H., Stehney, A. F., and Lucas Jr., H. F.: The effect of meteorological variables upon the vertical and temporal distributions of atmospheric radon, J. Geophys. Res., 65, 1223-1238, 1960.

Ohara, T., Akimoto, H., Kurokawa, J., Horii, N., Yamaji, K., Yan, X., and Hayasaka, T.: An Asian emission inventory of anthropogenic emission sources for the period 1980-2020, Atmos. Chem. Phys., 7, 4419-4444, doi:10.5194/acp-7-4419-2007, 2007.

Olivier, J. G. J., van Aardenne, J. A., Dentener, F., Pagliari, V., Ganzeveld, L. N., and Peters, J. A. H. W.: Recent trends in global greenhouse gas emissions: regional trends 1970-2000 and spatial distribution of key sources in 2000, Environ. Sci., 2, 81-99, doi:10.1080/15693430500400345, 2005.

Palmer, P. I., Jacob, D. J., Jones, D. B. A., Heald, C. L., Yantosca, R. M., Logan, J. A., Sachse, G. W., and Streets, D. G.: Inverting for emissions of carbon monoxide from Asia using aircraft observations over the western Pacific, J. Geophys. Res., 108, 8828, doi:10.1029/2003JD003397, 2003.

Palmer, P. I., Suntharalingam, P., Jones, D. B. A., Jacob, D. J., Streets, D. G., Fu, Q., Vay, S. A., and Sachse, G. W.: Using $\mathrm{CO}_{2}$ :CO correlations to improve inverse analyses of carbon fluxes, J. Geophys. Res., 111, D12318, doi:10.1029/2005JD006697, 2006.

Parrish, D. D., Hahn, C. J., Williams, E. J., Norton, R. B., Fehsenfeld, F. C., Singh, H. B., Shetter, J. D., Gandrud, B. W., and Ridley, B. A.: Indications of photochemical histories of Pacific air masses from measurements of atmospheric trace species at Pt. Arena, California, J. Geophys. Res., 97, 15883-15901, 1992.

Sawa, Y., Tanimoto, H., Yonemura, S., Matsueda, H., Wada, A, Taguchi, S., Hayasaka, T., Tsuruta, H., Tohjima, Y., Mukai, H., Kikuchi, N., Katagiri, S., and Tsuboi, K.: Widespread pollution events of carbon monoxide observed over the western North Pacific during the East Asian Regional Experiment (EAREX) 2005 campaign, J. Geophys. Res., 112, D22S26, doi:10.1029/2006JD008055, 2007.

Schmidt, M., Graul, R., Sartorius, H., and Levin, I.: Carbon dioxide and methane in continental Europe: a climatology, and ${ }^{222}$ Radon-based emission estimates, Tellus, 48B, 457-473, 1996.

Schmidt, M., Glatzel-Mattheier, H., Sartorius, H., Worthy, D. E., and Levin, I.: Western European $\mathrm{N}_{2} \mathrm{O}$ emissions - a top down approach based on atmospheric observations, J. Geophys. Res., 106, 5507-5516, 2001.

Schmidt, M., Graul, R., Sartorius, H., and Levin, I.: The Schauinsland $\mathrm{CO}_{2}$ record: 30 years of continental observations and their implications for the variability of the European $\mathrm{CO}_{2}$ budget, $\mathrm{J}$. Geophys. Res., 108, 4619, doi:10.1029/2002JD003085, 2003.

Servant, J.: Temporal and spatial variations of the concentration of the shortlived decay products of radon in the lower atmosphere, Tellus, 28, 663-671, 1966.

Spivakovsky, C. M., Logan, J. A., Montzka, S. A., Balkanski, Y. J., Foreman-Fowler, M., Jones, D. B.A., Horowitz, L. W., Fusco, A. C., Brenninkmeijer, C. A. M., Prather, M .J., Wofsy, S. C., and McElroy, M. B.: Three-dimensional climatological distribution of tropospheric OH: Update and evaluation, J. Geophys. Res., 105, 8931-8980, 2000.

Streets D. G., Bond, T. C., Carmichael, G. R., Fernandes, S. D., Fu, Q., He, D., Klimont, Z., Nelson, S. M., Tsai, N. Y., Wand, M. 
Q., Woo, J.-H., and Yarber, K. F.: An inventory of gaseous and primary aerosol emissions in Asia in the year 2000, J. Geophys. Res., 108, 8809, doi:10.1029/2002JD003093, 2003.

Suntharalingam, P., Jacob, D. J., Palmer, P. I., Logan, J. A., Yantosca, R. M., Xiao, Y., Evans, M. J., Streets, D. G., Vay, S. L., and Sachse, G. W.: Improved quantification of Chinese carbon fluxes using $\mathrm{CO}_{2} / \mathrm{CO}$ correlations in Asian outflow, J. Geophys. Res., 109, D18S18, doi:10.1029/2003JD004362, 2004.

Taguchi, S.: A three-dimensional model of atmospheric $\mathrm{CO}_{2}$ transport based on analyzed winds: model description and simulation results for TRANSCOM, J. Geophys. Res., 101, 15099-15109, 1996.

Taguchi, S., Matsueda, H., Inoue, H. Y., and Sawa, Y.: Long-range transport of $\mathrm{CO}$ from tropical ground to upper troposphere: A case study for Southeast Asia in October 1997, Tellus, 54B, 2240, 2002a.

Taguchi, S., Iida, T., and Moriizumi, J.: Evaluation of the atmospheric transport model NIRE-CTM-96 by using measured radon-222 concentrations, Tellus, 54B, 250-268, 2002b.

Taguchi, S., Law, R. M., Rödenbeck, C., Patra, P. K., Maksyutov, S., Zahorowski, W., Sartorius, H., and Levin, I.: TransCom continuous experiment: comparison of ${ }^{222} \mathrm{Rn}$ transport at hourly time scales at three stations in Germany, Atmos. Chem. Phys., 11, 10071-10084, doi:10.5194/acp-11-10071-2011, 2011.

Takigawa, M., Sudo, K., Akimoto, H., Kita, K., Takegawa, N., Kondo, Y., and Takahashi, M.: Estimation of the contribution of international transport during the PEACE campaign by using a global model, J. Geophys. Res., 110, D21313, doi:10.1029/2005JD006226, 2005.

Tanimoto, H., Sawa, Y., Matsueda, H., Uno, I., Ohara, T., Yamaji, K., Kurokawa, J., and Yonemura, S.: Significant latitudinal gradient in the surface ozone spring maximum over East Asia, Geophys. Res. Lett., 32, L21805, doi:10.1029/2005GL023514, 2005.

Tanimoto, H., Sawa, Y., Yonemura, S., Yumimoto, K., Matsueda, H., Uno, I., Hayasaka, T., Mukai, H., Tohjima, Y., Tsuboi, K., and Zhang, L.: Diagnosing recent CO emissions and ozone evolution in East Asia using coordinated surface observations, adjoint inverse modeling, and MOPITT satellite data, Atmos. Chem. Phys., 8, 3867-3880, doi:10.5194/acp-8-3867-2008, 2008.

Thom, M., Bösinger, R., Schmidt, M., and Levin, I.: The regional budget of atmospheric methane of a highly populated area, Chemosphere, 26(1-4), 143-160, 1993.
Troen, I., and Mahrt, L.: A simple model of the atmosphere boundary layer, sensitively to surface evaporation, Bounda. Layer Meteorol., 37, 129-148, 1986.

Tsutsumi, Y., Mori, K., Ikegami, M., Tashiro, T., and Tsuboi, K.: Long-term trends of greenhouse gases in regional and background events observed during 1998-2004 at Yonagunijima located to the east of the Asian continent, Atmos. Environ., 40, 5868-5879, 2006.

van der Werf, G. R., Randerson, J. T., Giglio, L., Collatz, G. J., Mu, M., Kasibhatla, P. S., Morton, D.C., DeFries, R. S., Jin, Y., and van Leeuwen, T. T.: Global fire emissions and the contribution of deforestation, savanna, forest, agricultural, and peat fires (19972009), Atmos. Chem. Phys., 10, 11707-11735, doi:10.5194/acp10-11707-2010, 2010.

Wada, A., Sawa, Y., Matsueda, H., Taguchi, S., Murayama, S., Okubo, S., and Tsutsumi, Y.: Influence of continental air mass transport on atmospheric $\mathrm{CO}_{2}$ in the western North Pacific, J. Geophys. Res., 112, D07311, doi:10.1029/2006JD007552, 2007.

Wada, A., Murayama, S., Kondo, H., Matsueda, H., Sawa, Y., and Tsuboi, K.: Development of a compact and sensitive electrostatic Radon-222 measuring system for use in atmospheric observation, J. Meteor. Soc. Jpn, 88, 123-134, 2010.

Wada, A.: A Study of Emissions and Transport of Trace Gases in East Asia Based on Atmospheric Radon Observations over the Western North Pacific, Ph.D. thesis, 184 pp., Tohoku Univ., Sendai, Japan, 2011.

Wada, A., Matsueda, H., Sawa, Y., Tsuboi, K., and Okubo, S.: Seasonal variation of enhancement ratios of trace gases observed over 10 years in the western North Pacific, Atmos. Environ., 45, 2129-2137, doi:10.1016/j.atmosenv.2011.01.043, 2011.

Wilkening, M. H. and Clements, W. E.: Radon-222 from the ocean surface, J. Geophys. Res., 80, 3828-3830, 1975.

Xiao, Y., Jacob, D. J., Wang, J. S., Logan, J. A., Palmer, P. I., Suntharalingam, P., Yantosca, R. M., Sachse, G. W., Blake, D. R., and Streets, D. G.: Constraints on Asian and European sources of methane from $\mathrm{CH}_{4}-\mathrm{C}_{2} \mathrm{H}_{6}$-CO correlations in Asian outflow, J. Geophys. Res., 109, D15S16, doi:10.1029/2003JD004475, 2004

Zhang, Q., Streets, D. G., Carmichael, G. R., He, K. B., Huo, H., Kannari, A., Klimont, Z., Park, I. S., Reddy, S., Fu, J. S., Chen, D., Duan, L., Lei, Y., Wang, L. T., and Yao, Z. L.: Asian emissions in 2006 for the NASA INTEX-B mission, Atmos. Chem. Phys., 9, 5131-5153, doi:10.5194/acp-9-5131-2009, 2009. 